\title{
Present Situation and Trend of Diversified Development of Art Design Education System in China
}

\author{
Yonghua Jing \\ Minsheng College \\ Henan University \\ Kaifeng, Henan, China
}

\begin{abstract}
According to the features of art design education at present in China, in the development process of art design education and teaching system, the characteristics of art design education shall be analyzed and determined, the teaching contents of art design education shall be mastered, the whole development tendency of art design education shall be comprehensively analyzed and researched, which are basic requirements for establishing a whole system of art design education. From the overall situation, since the major of art design is started late in China, people are looking for the pathway that may inherit Chinese culture at the same time integrating with the international culture during the whole course of system establishment. Although there were many uncertain factors in the process of building this pathway, the establishment of a whole art design education system needs a long term. In this paper, the importance of art design education in the diversified development, the current situation of Chinese art design education development and diversified development trend of art design education are described.
\end{abstract}

Keywords-Art design education system; diversification; development trend

\section{INTRODUCTION}

The characteristics of the major of art design determine its teaching shall go through diversified development. Not only knowledge on the textbooks shall be learnt, students shall be exposed to the global culture as much as possible to improve their knowledge level. As things stand, art design education in China is far to reach the world level, the reasons are too many problems existing in Chinese education system needing to be solved, traditional and single educational mode, which can't meet the social demand for art design professionals. Therefore, Chinese art design teaching system shall march towards diversified development continuously in or.

\section{SIGNIFICANCE OF DIVERSIFIED DEVELOPMENT FOR ART DESIGN EDUCATION}

Art design is a very professional course. Students will go through constant tests from learning to coming upon the stage. According to the need on art design at present in China, in society art design is required to meet the requirements of different customers, irrespective of district, gender and age. China is a country with a vast area, so north and south difference is larger, both in terms of culture and local characteristics. Therefore, art design must be based on the local culture, economic and development features. The requirements of customers shall be valued in design. Different customers have different requirements, so the designers shall adjust accordingly. Diversified art design professionals are needed in society; as a result, the teaching system must go through diversified adjustment in the professional teaching of universities and colleges so that students can have an all-round development.

\section{CURRENT DEVELOPMENT SituAtion OF CHINESE ART DESIGN EDUCATION}

\section{A. Too large scale of students}

In China many colleges and universities have opened the major of art design, so the scale of the students is very large. Every year there are large numbers of art design professional graduates. However, a large number does not equal to a strong expertise. A lot of students majored in art design are facing the problem of employment difficulty after their graduation. Many schools start only from their own economic benefits and recruit students in a large scale. The tuition of art design is relatively higher than other majors, and a large number of students increased a lot of revenue for the school. Parents hope their children can be admitted to a university, but a lot of students have non-ideal achievement, so parents will send them to university of arts, because art design has no many requirements on the students. Many reasons lead to the overload students in the major of art design in China, but they are facing a huge challenge in terms of employment.

\section{B. Seriously imbalanced course system}

The large number of students leads to serious imbalance of teaching system in some colleges and universities. Because China's art design teaching is still in the primary stage of development, but reasonable schemes for shortening the gap between various colleges and universities, China and the world are not yet worked out and actually implemented. 
Many colleges have set the majors before improving their system, and then recruit students in a large scale without developing a long-term plan and teaching system. Only with established school-running objective, diversified development system, the colleges and universities are responsible for the students majored in art design and the society when recruiting.

\section{Low quality of teachers}

The teacher is the most important in the teaching of each course. Stability is pursued in the traditional teaching system, and the teachers are required to cope with shifting events by sticking to a fundamental principle. However, under the new education system reform, teachers should constantly improve themselves, adding new faculty, bring new ideas to art design professional teaching. But, in terms of the actual state of affairs, many teachers in the major of art design in colleges and universities are not graduated from this major. A lot of colleges and universities set the major of art design before looking for teachers, thus resulting in lack of faculty. Non-professional teachers are made to teach firstly, which has a large impact on the professional learning of students.

\section{TeAChing nOt MeEting The NeEds OF SociEty}

A final goal of the teaching of art design education in colleges and universities is the output of professional talents for the society in stead of simply guaranteeing students to complete the teaching content. Therefore, teaching of specialized courses in colleges and universities in China is not included in the nine-year compulsory education, but professional. A lot of students majored in art design are not engaged in related work after they going out of the school, so their learning for several years during the college years are in vain. In society, the requirements on the art design professionals are high, but most of students from vocational colleges are substandard in their specialized courses, totally unable to meet the need of social posts. Consequently, many students must give up their own major and select other working posts in order to survive.

\section{DiversifIED DEVELOPMENT TREND OF ART DESIGN} EDUCATION

\section{A. Diversified development trend of art design in curriculum structure}

The major of art design contains a wide range of contents, not only limited in design but needing a certain processing. So, in the teaching of art design, students should be aware of the characteristics of the major. Simply memorizing knowledge is not enough in the learning of art design, continuous accumulation and practice are needed. In the curriculum structure, the teachers must arrange reasonably, teach progressively to infiltrate knowledge slowly to the students, not anxious for success. In the teaching process of art design, students' innovation ability and aesthetic ability shall be fostered. Creativity is needed by every major, and aesthetic appreciation is very critical to the major of art design. Only when the both are combined better, more perfect design will be worked out.
For the major of art design, the diversification of curriculum structure is to change the traditional course arrangement mode, dividing the courses into three major parts, i.e. foundation, design and practice so that course teaching is clear and learning efficiency of student is improved. For the students majored in the art design, the teachers may arrange more optional courses related to the major for the students to choose so that the students may get diversified development.

\section{B. Diversification of art design teaching contents}

For the teaching of art design, some contents of classical culture may be added in. The major of art design is to combine the reality with the art perfectly to make a brand new creation. If a designer from the major of art design has no clue of the traditional culture, he may not design better works. Therefore, it is necessary to add classical culture in the teaching of art design which is also the reflection of diversification of teaching content. For the teaching content of art design, in addition to professional courses, some advanced technologies shall also be added in. The good things shall be absorbed constantly to make the contents of art design richer.

In spite that the major of art design has been set for thirty years in China, the teaching system of art design is not improved, and there is still lack of a unified teaching standard for the new education contents. On the premise of guaranteeing the students to learn the basic knowledge of art design, the teachers shall supplement new knowledge in terms of technology and new contents in terms of art design in society to the students so that learning of students majored in art design is connected to the actual need in society, which is also a reflection of diversification of teaching content. In the other countries in the world, their colleges and universities have diversified teaching contents in the major of art design, and many teaching contents and practical contents beyond the course are added. In this way, the diversified development of students is met, and a better foundation is laid for the practice in the future. Therefore, diversification of teaching content of art design will be a development trend for the education in the world

\section{Diversified teaching methods in the major of art design}

On condition that teaching tasks and contents are clear and definite, teaching methods are of great importance. Although now many colleges and universities are studying the teaching methods suitable for the student development, no much progress has been made. In terms of teaching method for the major of art design, the theory must be combined with practice, especially the practical courses, because art design is a major with strong practicalness. However, the practical curses are fewer in the teaching of art design in our country, resulting in low practical ability of student. Most of the practices are done with computers. To the major of art design, thinking and doing shall be combined perfectly, and many factors shall be taken into account. But, thinking is not imaging without foundation, 
conception shall be made in combination with the theoretical knowledge, and then design will be completed on the basis of conception.

In the learning of practical course of art design, teaching contents and some actual design project may also be combined. The project mentioned here can be fictitious or actual design project of enterprises. Colleges and universities may be cooperated with the enterprises so that students can attend practical courses actually instead of the computer rooms. Since students majored in art design will be unable to competent to their work positions if they are staying on the learning of theory.

Case: For a five-year system major of art design, the school may divide it reasonably. For the first three years, students can study theoretical knowledge in schools in combination with practical operation in terms of computer and freehand sketching. In the fourth year teaching, the school may send students to cooperative enterprises to practice that is practice learning in actual projects. After completion of one year practice learning, students shall continue their fifth year learning in the school to perfectly combine theory with actuality. Such teaching methods allow student to lay a good theoretical and practical foundation for the future employment and increase the employment rate of art design major.

\section{CONCLUSION}

Although art design major in China is still in the primary stage of development, it has a bright prospect. As a place for outputting professionals to the society, colleges and universities must upgrade their teaching systems constantly. Diversified teaching system is a necessary trend for the development of art design teaching. Teachers shall make a reasonable adjustment on the teaching contents, course arrangement and teaching methods so that students may get all-round development. Art design is a course with very strong practicalness, so, teaching of art design shall not be maintained on the theory teaching. Students' practical ability shall be strengthened continuously. As long as colleges and universities make a reform on the diversification of teaching system, students majored in art design may get all-round development.

\section{REFERENCES}

[1] Yao Wenting, Zhang Linyan, Discussion on the Development Trend of Art design Educational System Diversification in China [J], China Packaging Industry, 2014 (22).

[2] Liu Junyao, Analysis on the Diversified Development Mode of Art design Educational System in China [J], Time Education, 2015 (05).

[3] Yu Zhongxing, Opinions on the Diversified Development Directions of Art design Educational System in China [J], Journal of

[4] Pang Shanshan, An Zunzhi, Exploration on the Diversified Development of Art design Educational System in China [J], Educational Research on Arts, 2013 (15).
[5] Zhang Ce, Exploration and Research on the Setting of Practical Courses in Art Design Education in High Schools in China [D], Hunan Normal University, 2014.

[6] Xiao Pei, Education for Art Design in Colleges in Contemporary China [D], Hunan Normal University, 2012.

[7] Yang Yabo, Primary Investigation on the Laws of Art Design Education in High Schools in China [D], Shandong University, 2012.

[8] Tong Yijie, Research on the Development Characteristics of Art design in China since Reform and Opening-up [D], Wuhan University of Technology, 2012.

[9] Leng Xianping, Discussion on the Spread of Humanistic Spirit in Education for Art Design in Colleges — Taking Huazhong University of Science and Technology as an Example [J], Design Research, 2014 (01) 